\title{
Complexing agent effect on the stoichiometric ratio of the electrochemically prepared $\mathrm{CuInSe}{ }_{2}$ thin films
}

\author{
S. Beyhan ${ }^{\mathrm{a}}$, S. Suzer ${ }^{\mathrm{b}}$, F. Kadırgan ${ }^{\mathrm{a}, *}$ \\ ${ }^{a}$ Chemistry Department, Istanbul Technical University, Ayazaga Kampusu, 34469 Maslak/Istanbul, Turkey \\ ${ }^{\mathrm{b}}$ Chemistry Department, Bilkent University, 06533 Bilkent/Ankara, Turkey \\ Received 15 February 2007; accepted 26 June 2007 \\ Available online 27 September 2007
}

\begin{abstract}
The electrodeposition of $\mathrm{CuInSe}_{2}$ is investigated to improve the stoichiometric properties of CuInSe $\mathrm{Se}_{2}$ layers on indium tin oxide (ITO)coated glass substrates and to develop one-step electrodeposition method for solar cell applications. XPS was utilized for the characterization of the surface properties of $\mathrm{CuInSe}_{2}$ layers. The influence of the complexing agent, e.g. benzotriazole, bulk concentration of $\mathrm{Cu}$ and $\mathrm{Se}$ and deposition potentials on the stoichiometric properties, are discussed.
\end{abstract}

(C) 2007 Elsevier B.V. All rights reserved.

Keywords: Thin film solar cells; CuInSe ${ }_{2}$; Electrodeposition

\section{Introduction}

$\mathrm{CuInSe}_{2}$ (CIS) has a bandgap energy $\left(0.95<E_{\mathrm{g}}<\right.$ $1.04 \mathrm{eV}$ ) and a light absorption coefficient very suitable to the photovoltaic conversion of solar energy [1]. Furthermore, having the plastic/flexible substrate CIS-based flexible solar cells are lighter, thinner and unbreakable, a fact which is interesting for the development of industrial applications. Electrodeposition is a very useful technique for developing CIS-based solar cells as compared to the traditional vapour deposition methods. Preparation of CIS films using electro-deposition may be either a two-step process, namely (a) sequential electrodeposition of $\mathrm{Cu}$ and In layers on a conductive glass substrate followed by selenization of $\mathrm{Cu} / \mathrm{In}$ stacked layer at elevated temperatures in an atmosphere containing $\mathrm{H}_{2} \mathrm{Se}$ gas $[2,3]$ or (b) after preparation of precursor films of $\mathrm{Cu}-\mathrm{In}-\mathrm{Se}$ by electrodeposition, it is subsequently integrated with the physical evaporation technique [4], or (c) prepared in one step by codeposition of $\mathrm{Cu}$, In and Se simultaneously [5]. Several attempts have been made to employ the one-step process on which the CIS film is potentiostically grown by

\footnotetext{
${ }^{*}$ Corresponding author. Tel.: + 902122853159 ; fax: + 902122856386 .

E-mail address: kadirgan@itu.edu.tr (F. Kadırgan).
}

co-deposition of $\mathrm{Cu}$, In and Se simultaneously; however, some difficulties have been met [6-8].

An important problem in the development of this technique is the control of the sample composition. It is shown that the film composition should be very close to CIS to obtain higher efficiency in thin film solar cell. This stochiometric relation between the $\mathrm{Cu}$, In and $\mathrm{Se}$ atoms is directly related to the electrodeposition conditions and concentrations. According to the Nernst equation, the electrode potentials for selenium and copper will, of course, precede the deposition of indium. This problem has been overcome by using a complexing agent (such as citric acid, triethanolamine, $\mathrm{CN}^{-}$, etc.) in order to shift the copper deposition potential in the negative direction bringing it closer to the In deposition potential $[9,10]$. It is seen in the literature that both the dissolution and deposition reactions of $\mathrm{Cu}$ are inhibited by the benzotriazole (BTA) adsorption [11,12]. It is also observed that with an excess of $\mathrm{In}^{3+}$ in the solution, the ratio of $\mathrm{Se}^{4+}$ and $\mathrm{Cu}^{2+}$ fluxes is the key parameter setting the composition. Lower concentration of $\mathrm{In}^{3+}$ than $10^{-3} \mathrm{M}$ involve the deposition of elemental selenium. In this case, the electrodeposition process is limited by the diffusion of three species [9].

In this work, CIS thin films has been deposited potentiostatically on conductive and transparent indium 
tin oxide (ITO)-coated glass substrates from an aqueous solution containing $\mathrm{CuCl}_{2}, \mathrm{In}_{2}\left(\mathrm{SO}_{4}\right)_{3}, \mathrm{H}_{2} \mathrm{SeO}_{3}, \mathrm{LiCl}$ in a pHydrion buffer $(\mathrm{pH} 3)$. The effect of adding BTA as a complexing agent was studied. pHydrion buffer provides stability of electrodeposition bath and improved deposition process for producing stoichiometric CIS thin films [13]. The codeposition process of $\mathrm{Cu}-\mathrm{In}-\mathrm{Se}$ system was studied with an excess of $\mathrm{In}^{3+}$ in the solution $\left(\left[\mathrm{In}^{3+}\right]>1 \mathrm{mM}\right)$, the ratio of $\mathrm{Se}^{4+}$ and $\mathrm{Cu}^{2+}$ concentrations are the key parameters setting the composition. Indium composition is normalized to 1 during the determination of surface composition, because of the possible diffusion of the In ions to the surface of the films from ITO-coated substrates. The stoichiometry of electrodeposited thin films is controlled by deposition potential, $\mathrm{Cu}$ and Se bulk concentration and BTA. The thin films compositions of the resulting films were characterized using XPS.

\section{Experimental}

Codepositions of $\mathrm{Cu}-\mathrm{In}-\mathrm{Se}$ by the electrodeposition process were performed from a bath containing $\mathrm{CuCl}_{2}$ between 1.14 and $4.55 \mathrm{mM}, \mathrm{In}_{2}\left(\mathrm{SO}_{4}\right)_{3} 3.75 \mathrm{mM}, \mathrm{H}_{2} \mathrm{SeO}_{3}$ from 6.89 to $13.78 \mathrm{mM}, \mathrm{LiCl} 0.7 \mathrm{M}$ and BTA $1 \mathrm{mM}$ dissolved in pHydrion buffer (pH 3).

Thin films were prepared by using a three-electrode cell, the counter electrode was Pt gauze, reference electrode was SCE and the substrate was ITO/glass. Voltalab PGZ 301 Impedance Spectroscopy was used to prepare the electrodeposited films. The thin films were electroplated at room temperature $\left(25^{\circ} \mathrm{C}\right)$ without stirring the electrolyte solution.

\section{Result and discussion}

Cathodic electrodeposition of CIS is based on coreduction of $\mathrm{Cu}^{2+} / \mathrm{Cu}, \mathrm{In}^{3+} / \mathrm{In}$ and the reduction of $\mathrm{HSeO}_{2}^{+}$species [14]. It is known that for ternary compounds, the available free energy from compound formation results in a shift of the metal deposition potentials to positive values (relative to the standard potentials $E^{0}$ )

According to the Nernst equations:

$$
\begin{array}{lr}
\mathrm{Cu}^{2+}(\mathrm{aq})+2 \mathrm{e}^{-} \rightarrow \mathrm{Cu}(\mathrm{s}) & 0.337 \\
\mathrm{In}^{3+}(\mathrm{aq})+3 \mathrm{e}^{-} \rightarrow \mathrm{In}(\mathrm{s}) & -0.342 \\
\mathrm{HSeO}_{2}^{+}+4 \mathrm{e}^{-}+4 \mathrm{H}^{+}+\mathrm{OH}^{-} \rightarrow & 0.741 \\
\mathrm{Se}(\mathrm{s})+3 \mathrm{H}_{2} \mathrm{O} &
\end{array}
$$$$
\text { ( } E^{0} \text { vs. SHE) }
$$

the electrode potentials for selenium and copper are more positive than that of indium.

Thus the deposition of selenium and copper will precede the deposition of indium. Se electrodeposition potential depends to the $\mathrm{pH}$. Consequently, for the simultaneous deposition of $\mathrm{Cu}$, In and $\mathrm{Se}$, we may adjust the $\mathrm{pH}$ and concentration of the electrolyte such that the electrode potential of the individual deposits may come closer to each other. For example, a higher concentration of indium makes the electrode potential of indium closer to that of $\mathrm{Cu}$ and Se. For the direct deposition of CIS the $\mathrm{pH}$ of the electrolyte should lie between 0.5 and 9.5 and the deposition potential should lie between -0.05 and $-0.75 \mathrm{~V} /$ NHE. A straightforward way to shift the reduction potentials of $\mathrm{Cu}$ and $\mathrm{Se}$ in this potential range is to complex, the copper ions with ligands forming complexes with high stability constants should be used. On the other hand, the ligand used for complexing $\mathrm{Cu}$ should form only weak complexes with $\mathrm{In}^{3+}$ ions so that the potential required for the underpotential deposition of $\mathrm{In}^{3+}$ into CIS would not be shifted outside the stability region of water.

It is well known that $\mathrm{Cu}$ gives the strong complexing reaction with BTA [12]. This negative shift of $\mathrm{Cu}$ reduction peak potential approves complex formation between the $\mathrm{Cu}$ and BTAH. As seen in Fig. 1, the reduction potential of $\mathrm{Cu}^{2+}$ is shifted $(\sim 180 \mathrm{mV})$ to more negative potentials in the presence of BTA. Reduction of $\mathrm{Cu}$ occurred at $\sim-580 \mathrm{mV}$ in the presence of BTA. Such complexes are known to form in acidic solution when BTA is chemisorbed at the electrode surface, according to the following reaction.

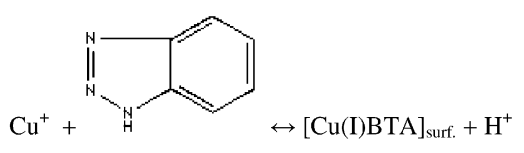

We checked the effect of BTA on In and Se ions under same experimental conditions.

Fig. 2 illustrates the effect of BTA on the $\mathrm{Se}^{4+}$ reduction potential with and without BTA comparing the cyclic voltammograms. The first reduction peak which begins at about $-0.3 \mathrm{~V}$ giving two reduction peaks at $-660 \mathrm{mV}$ and $-820 \mathrm{mV}$ probably corresponding to the $\mathrm{HSeO}_{3}^{-}$reduction

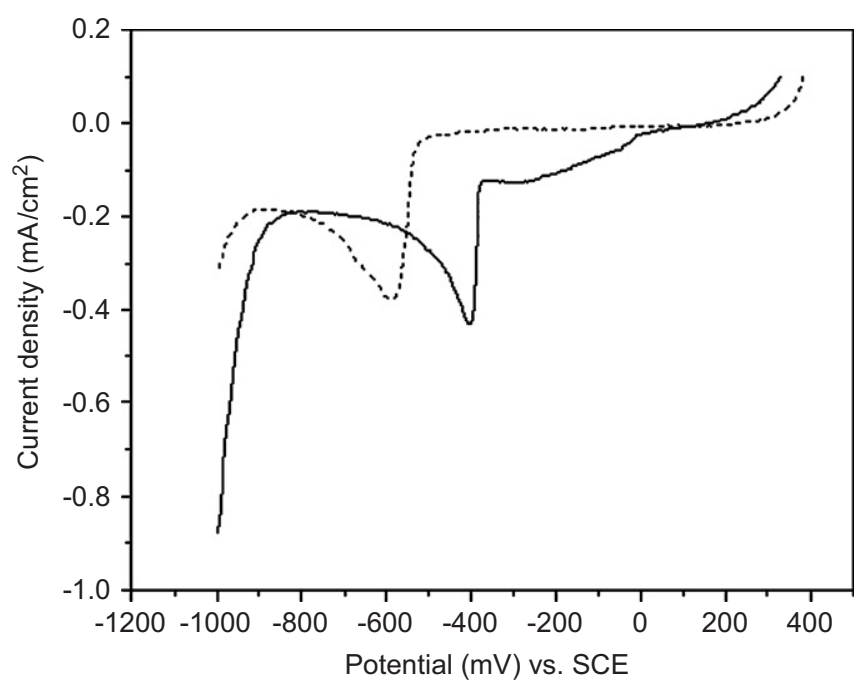

Fig. 1. Cyclic voltammograms of a ITO/glass electrode from $4.55 \mathrm{mM}$ $\mathrm{CuCl}_{2}, 0.7 \mathrm{M} \mathrm{LiCl}$ solutions with (dotted line) and without $1 \mathrm{mM}$ BTA (solid line) in the pHydrion buffer ( $\mathrm{pH} 3$ ) medium. 


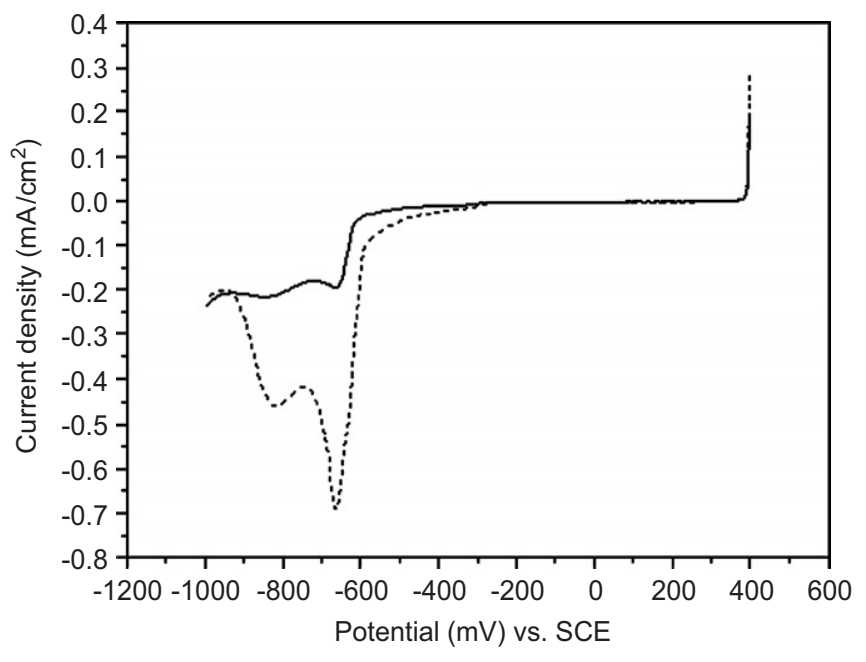

Fig. 2. Comparison of a ITO/glass electrode from $6.89 \mathrm{mM} \mathrm{H}_{2} \mathrm{SeO}_{3}$, $0.7 \mathrm{M} \mathrm{LiCl}$ in the pHydrion buffer ( $\mathrm{pH} 3$ ) medium with (dotted line) and without $1 \mathrm{mM}$ BTA (solid line).

to Se according to the following equation:

$$
\mathrm{HSeO}_{3}{ }^{-}(\mathrm{aq})+5 \mathrm{H}^{+}+4 \mathrm{e}^{-} \rightarrow \mathrm{Se}(\mathrm{s})+3 \mathrm{H}_{2} \mathrm{O} \text {. }
$$

The second peak at about $-0.82 \mathrm{~V}$ is probably corresponding to the $\mathrm{Se}$ reduction to $\mathrm{H}_{2} \mathrm{Se}$ (Eq. (6)), the standard reduction potential of which is $-0.621 \mathrm{~V}$ vs. $\mathrm{Ag} / \mathrm{AgCl}$.

$\mathrm{Se}(\mathrm{s})+2 \mathrm{H}^{+}(\mathrm{aq})+2 \mathrm{e}^{-} \leftrightarrow \mathrm{H}_{2} \mathrm{Se}(\mathrm{aq})$.

In the presence of BTA both of peak intensity corresponding to Se reduction increases. These enhancements may be explained by the increase of the reduction reactions rates. Any shift of potential did not observe. So, there was no complex formation between $\mathrm{H}_{2} \mathrm{SeO}_{3}$ and BTA. As the reduction rate of $\mathrm{Se}$ depends to the $\mathrm{pH}$, dissociation of the BTA may increase the $\mathrm{H}^{+}$ion concentration and then a higher reduction rate of $\mathrm{Se}$ is observed.

Fig. 3 shows the effect of BTA on In deposition. As it is seen, in the electrolyte free of complexing agent, In reduction begins from $-120 \mathrm{mV}$ and reduction rate increase giving a sharp decrease at current density from $-430 \mathrm{mV}$. With addition of BTA, reduction of In begins at about $-200 \mathrm{mV}$ but the rate of reaction is slower than the solution free of BTA. The sharp decrease in current density observed at $-680 \mathrm{mV}$. So; in the presence of BTA, $E_{\text {In }}$ shifts towards negative values. We could conclude that there was a complex formation between In and BTA.

Fig. 4 illustrates $I / V$ curves for ternary reduction of copper, indium and selenium with and without BTA. One reduction peak is observed for three cation reduction for both cases. In the electrolyte containing BTA, reduction peak potential was shifted about $75 \mathrm{mV}$ towards negative potentials (from -525 to $-580 \mathrm{mV}$ ). Reduction reaction begins at $-0.45 \mathrm{mV}$ giving a peak at $-580 \mathrm{mV}$.

The aim of this work was to define the electrochemical conditions leading to the stoichiometric relationship

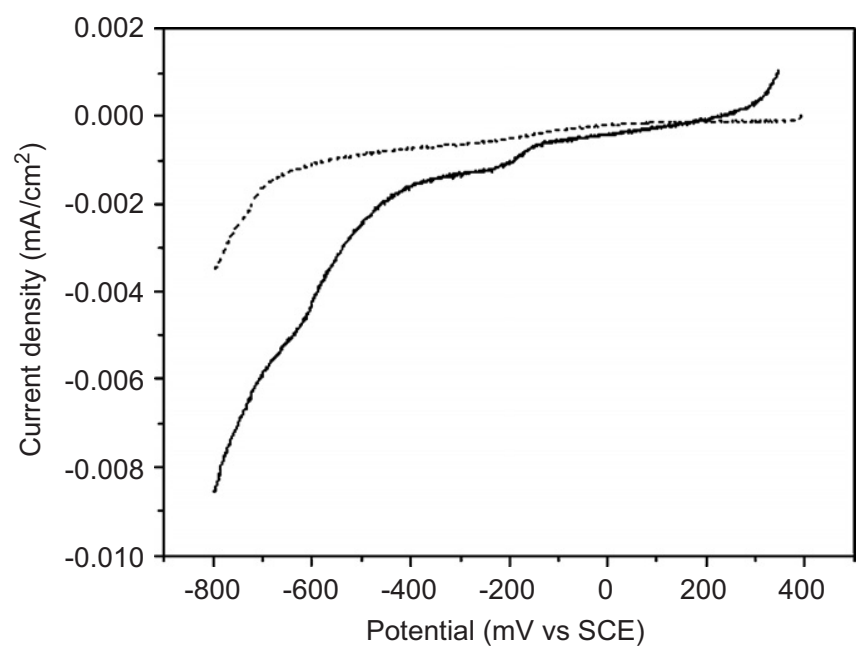

Fig. 3. Cyclic voltammograms ITO/glass electrode in a solution containg $3.75 \mathrm{mM} \mathrm{In} 2\left(\mathrm{SO}_{4}\right)_{3}, 0.7 \mathrm{M} \mathrm{LiCl}$, with $1 \mathrm{mM}$ BTA (dotted line) and without $1 \mathrm{mM}$ BTA (solid line) in the pHydrion buffer ( $\mathrm{pH} 3)$ medium.

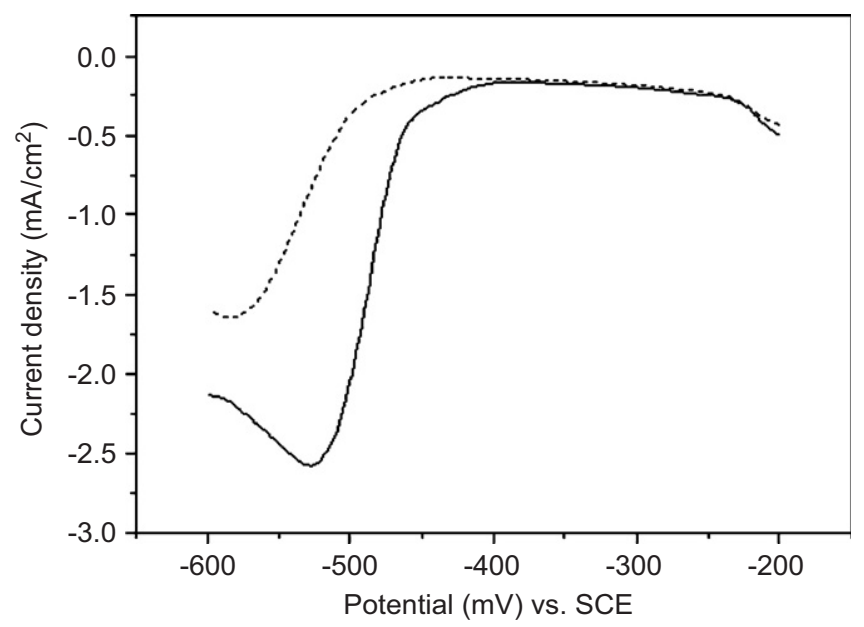

Fig. 4. Cyclic voltammograms of CIS deposition solutions $(4.55 \mathrm{mM}$ $\mathrm{CuCl}_{2}, 3.75 \mathrm{mM} \mathrm{In}{ }_{2}\left(\mathrm{SO}_{4}\right)_{3}, 6.89 \mathrm{mM} \mathrm{H}_{2} \mathrm{SeO}_{3}, 0.7 \mathrm{M} \mathrm{LiCl}$ with pHydrion buffer) with (dotted line) and without $1 \mathrm{mM}$ BTA (solid line).

between $\mathrm{Cu}$, Se (1:2). Two different deposition methods were tried: by cycling between two potential values; e.g. -0.2 and $-0.8 \mathrm{~V}$ and at constant potentials; e.g. $-0.45 \mathrm{~V}$ (onset reduction potential) and $-0.55 \mathrm{~V}$ (close to reduction peak potential). XPS measurements were performed to investigate the electrochemical depositions conditions effect on the chemical composition of the thin film surface. Indium composition is normalized to 1 during the determination of surface composition, because of the possible diffusion of the In ions to the surface of the films from the ITO-coated substrate. An excess of In concentration in the solution were also chosen to provide the ratio of $\mathrm{Se}^{4+}$ and $\mathrm{Cu}^{2+}$ fluxes as the key parameter, setting the composition.

Fig. 5 shows the XPS analysis results of $\mathrm{Cu}_{x} \mathrm{In}_{y} \mathrm{Se}_{z}$ ternary alloys under different electrochemical deposition conditions with and without BTA using $4.55 \mathrm{mM} \mathrm{CuCl}_{2}$, 


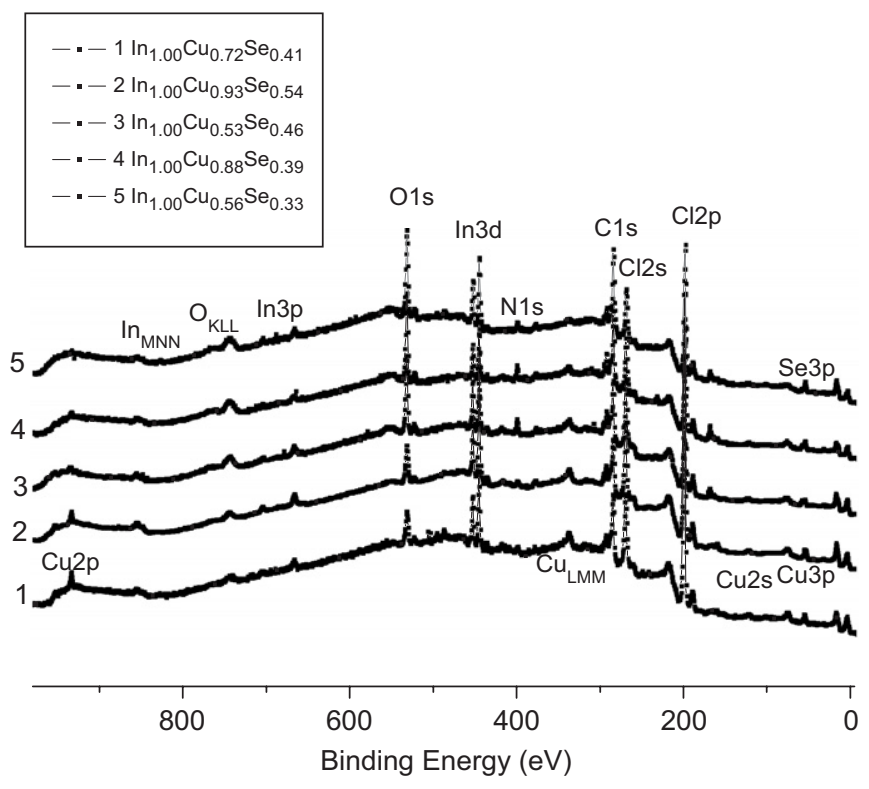

Fig. 5. XPS analysis of different samples prepared at different potentials in a solution containing $4.55 \mathrm{mM} \mathrm{CuCl} 2,3.75 \mathrm{mM} \mathrm{In}_{2}\left(\mathrm{SO}_{4}\right)_{3}, 6.89 \mathrm{mM}$ $\mathrm{H}_{2} \mathrm{SeO}_{3}, 0.7 \mathrm{M} \mathrm{LiCl}$ with pHydrion buffer.

Table 1

Variation of the thin film composition with BTA and without BTA (samples 4 and 5 are in a solution without BTA) at different potentials in a solution containing $4.55 \mathrm{mM} \mathrm{CuCl}, 3.75 \mathrm{mM} \mathrm{In}_{2}\left(\mathrm{SO}_{4}\right)_{3}, 6.89 \mathrm{mM}$ $\mathrm{H}_{2} \mathrm{SeO}_{3}, 0.7 \mathrm{M} \mathrm{LiCl}$ with pHydrion buffer

\begin{tabular}{llll}
\hline Sample & E $(V$ vs. SCE $)$ & BTA & Composition \\
\hline 1 & -0.45 & + & $\mathrm{In}_{1.00} \mathrm{Cu}_{0.72} \mathrm{Se}_{0.41}$ \\
2 & -0.68 & + & $\mathrm{In}_{1.00} \mathrm{Cu}_{0.93} \mathrm{Se}_{0.54}$ \\
3 & $(-0.2) \_(-0.8)$ & + & $\mathrm{In}_{1.00} \mathrm{Cu}_{0.53} \mathrm{Se}_{0.46}$ \\
4 & -0.45 & - & $\mathrm{In}_{1.00} \mathrm{Cu}_{0.88} \mathrm{Se}_{0.39}$ \\
5 & $(-0.2) \_(-0.8)$ & - & $\mathrm{In}_{1.00} \mathrm{Cu}_{0.56} \mathrm{Se}_{0.33}$ \\
\hline
\end{tabular}

$3.75 \mathrm{mM} \mathrm{In}_{2}\left(\mathrm{SO}_{4}\right)_{3}, 6.89 \mathrm{mM} \mathrm{H}_{2} \mathrm{SeO}_{3}, 0.7 \mathrm{M} \mathrm{LiCl}$ electrolyte and pHydrion buffer $(\mathrm{pH} 3)$. The results are given in Table 1 . Samples 1 , and 2 with $1 \mathrm{mM}$ BTA, sample 4 without BTA in the electrolyte at different constant deposition potentials; samples 3 with $1 \mathrm{mM}$ BTA, sample 5 without BTA by cycling between two potentials were studied. Although the films obtained are powdery cycling between two potentials, smooth and crystalline films are obtained at constant potential deposition conditions. It was found that while the stoichiometric ratio of $\mathrm{Cu}$ and $\mathrm{Se}$ could change in the presence of BTA depending on the deposition potential and deposition method, $\mathrm{Cu}$ rich surfaces are obtained even with the BTA used electrolytes (samples 4 and 5). The stoichiometric ratios were more far from the 1:2 when BTA was not used. However surface composition becomes richer in $\mathrm{Cu}$ and $\mathrm{Se}$ when the deposition potential was more negative in the presence of BTA (sample 2). But, never 1:2 ratio was obtained for $\mathrm{Cu} / \mathrm{Se}$ surface composition with the above-mentioned solution.

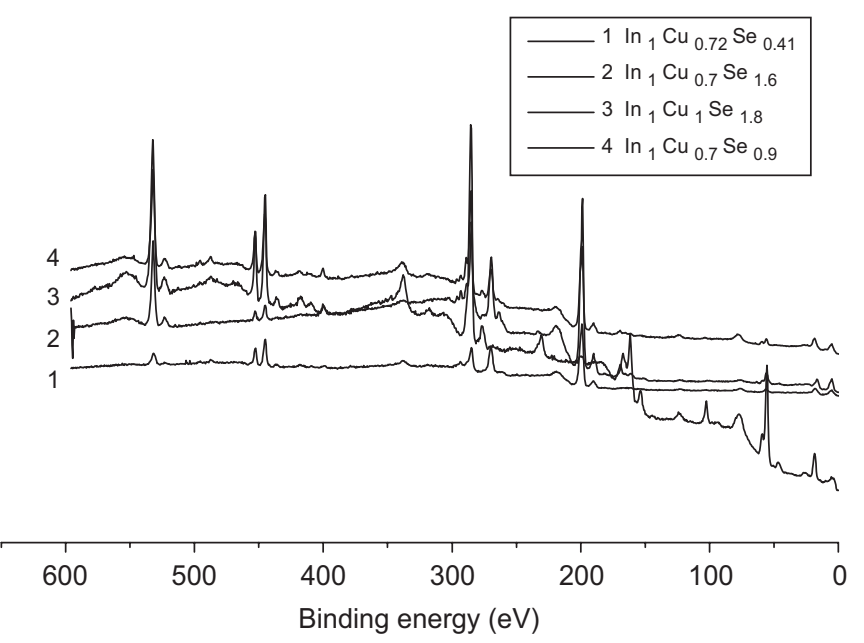

Fig. 6. XPS analysis of different samples prepared at different potentials and concentrations of $\mathrm{Cu}$ and $\mathrm{Se}$ in $3.75 \mathrm{mM} \mathrm{In} 2\left(\mathrm{SO}_{4}\right)_{3}$ and $0.7 \mathrm{M} \mathrm{LiCl}$ with pHydrion buffer.

Taking into consideration Nernst equations, to able to obtain the (1:2) ratio between the $\mathrm{Cu}$ and Se surface concentration, different bulk concentrations with different $[\mathrm{Se}] /[\mathrm{Cu}]$ ratio were tried at two deposition potentials with the presence of $1 \mathrm{mM}$ BTA and an excess of $I n$ in the electrolyte. Bulk concentration ratios of $[\mathrm{Se}] /[\mathrm{Cu}]$ were varied from 1.5 to 6 . The potentials are chosen as a result of the Figs. 1, 2 and 4 . While $-0.45 \mathrm{~V}$ was onset reduction potential of the cations, $-0.55 \mathrm{~V}$ was close to the reduction peak. The surface compositions of samples obtained were characterized by XPS measurements (Fig. 6). Table 2 gives the results of XPS analysis on $\mathrm{Cu}-\mathrm{In}-\mathrm{Se}$ ternary alloys obtained at different concentration of selenium and copper in a solution at $\mathrm{pH}$ 3. Deposition potential of samples 1, 2 and 4 were at $-0.45 \mathrm{~V} / \mathrm{SCE}$ and sample 3 was at $-0.55 \mathrm{~V} /$ SCE. It was observed that under the same deposition potential (samples 1 and 2) when we change the $[\mathrm{Se}] /[\mathrm{Cu}]$ ratio from 1.5 to 6 , Se surface composition was increased $\left(\mathrm{Cu}_{0.7} \mathrm{Se}_{1.6}\right)$. This may be a due to increase on the reduced Se surface concentration in the presence of further free BTA concentration and Se concentration. Changing the deposition potential to more negative values (sample 3 ) and keeping the ratio as 6 , both $\mathrm{Cu}$ and $\mathrm{Se}$ surface compositions were increased $\left(\mathrm{Cu}_{1} \mathrm{Se}_{1.8}\right)$ on the sample surface. Increase in the $\mathrm{Cu}$ composition may be the result of the shift of the deposition potential to negative values in the presence of BTA (Fig. 1). We also tried at this optimum condition (keeping the $[\mathrm{Se}] /[\mathrm{Cu}]$ ratio 6 ) to prepare a film in the absence of BTA. The observed composition was $\mathrm{Cu}_{0.4} \mathrm{Se}_{0.91}$. Decrease of the $\mathrm{Cu}$ content may be explained by the deposition potential value. In the absence of BTA, maximum reduction peak of $\mathrm{Cu}$ occurs at $-0.4 \mathrm{~V}$ (Fig. 1). At $-0.55 \mathrm{~V}$ reduction rate begins to decrease. However, at this potential we were observed an increase for Se (Fig. 2) as a result of high Se concentration.

Keeping the deposition potential at $-0.45 \mathrm{~V}$ and BTA concentration at $1 \mathrm{mM}$, if the $[\mathrm{Se}] /[\mathrm{Cu}]$ taken equal to 3 , the 
Table 2

XPS data of $\mathrm{CuInSe}_{2}$ coated on ITO glass under different selenium and copper concentrations in a solution at $\mathrm{pH} 3$ with $3.75 \mathrm{mM} \mathrm{In} 2\left(\mathrm{SO}_{4}\right)_{3}$ and $1 \mathrm{mM}$ BTA; In composition is normalized to 1.00

\begin{tabular}{llllll}
\hline AVB & E $(V$ vs. SCE $)$ & $\mathrm{Cu}(\mathrm{mM})$ & Se $(\mathrm{mM})$ & {$[\mathrm{Se}] /[\mathrm{Cu}]$} & Surface composition \\
\hline 1 & -0.45 & 4.55 & 6.89 & 1.5 & $\mathrm{In}_{1.00} \mathrm{Cu}_{0.72} \mathrm{Se}_{0.41}$ \\
2 & -0.45 & 1.14 & 6.89 & 6 & $\mathrm{In}_{1.00} \mathrm{Cu}_{0.7} \mathrm{Se}_{1.6}$ \\
3 & -0.55 & 1.14 & 6.89 & 6 & $\mathrm{In}_{1.00} \mathrm{Cu}_{1} \mathrm{Se}_{1.8}$ \\
4 & -0.45 & 4.55 & 13.78 & 3 & $\mathrm{In}_{1.00} \mathrm{Cu}_{0.7} \mathrm{Se}_{0.9}$ \\
\hline
\end{tabular}

stoichiometry between $\mathrm{Cu}$ and $\mathrm{Se}$ was obtained as $\left(\mathrm{Cu}_{0.7}\right.$ $\mathrm{Se}_{0.9}$ ) (sample 4).

\section{Conclusion}

Co-deposition of ternary compound $\mathrm{Cu}-\mathrm{In}-\mathrm{Se}$ was performed in one-step process using BTA as complexing agent. An excess of In concentration in the solution were also chosen to provide the ratio of $\mathrm{Se}^{4+}$ and $\mathrm{Cu}^{2+}$ fluxes as the key parameter, setting the composition. The effect of deposition potential, deposition method and concentration of the $\mathrm{Cu}$ and Se was observed on the surface composition of the films obtained. While the $\mathrm{Cu}$ gives a complexing reaction with BTA, Se gives a chemical reaction independent from the potential in the presence of BTA with the enhancement of reduction reaction rate. A smooth and transparent film formation with a good stoichiometry $\left(\mathrm{In}_{1} \mathrm{Cu}_{1} \mathrm{Se}_{1.8}\right)$ obtained under $-0.55 \mathrm{~V} / \mathrm{SCE}$ at $\mathrm{pH} 3$ with $1 \mathrm{mM}$ BTA keeping the [Se]/ $[\mathrm{Cu}]$ ratio equal to 6 . At this optimum condition the surface composition of the film prepared in the absence of BTA was far from the preferred values due to electrochemical deposition properties of $\mathrm{Cu}$ and $\mathrm{Se}$ on this potential value.

The work will continue preparing a solar cell with obtained films.

\section{References}

[1] F.J. Pern, J. Goral, R.J. Matson, T.A. Gessert, R. Noufi, Sol. Cells 24 (2001) 81.

[2] F. Kadirgan, in: H.S. Nalwa (Ed.), Handbook of Advanced Electronic and Photonic Materials and Devices, vol. 10, Academic Press, San Diego, 2001, pp. 301-309.

[3] P.J. Sebastian, A.M. Fernandez, A. Sanchez, Sol. Energy Mat. Sol. Cells 52 (1996) 199.

[4] R.N. Bhattacharya, A.M. Fernandez, M.A. Contreraz, J. Keane, A.I. tennant, K. Ramanathan, J.R. Tuttle, R.N. Noufi, A.M. Hermann, J. Electrochem. Soc. 43 (1996) 854.

[5] L. Thouin, S. Massaccesi, S. Sanchez, J. Vedel, J. Electroanal. Chem. 374 (1994) 81.

[6] Y. Ueno, H. Kawai, T. Sigiura, H. Minoura, Thin Solid Films 157 (1988) 159

[7] D. Pottier, G. Maurin, J. Appl. Electrochem. 19 (1989) 361.

[8] R.N. Bhattacharya, J. Electrochem.Soc. 130 (10) (1983) 2040.

[9] L. Thouin, J. Vedel, J. Electrochem. Soc. 142 (9) (1995) 2997.

[10] R.N. Bhattacharya, K. Rajeshwar, Sol. Cells 16 (1986) 237.

[11] M. Kemmell, M. Ritala, H. Saloniemi, M. Leskela, T. Sajavaara, E. Rauhala, J. Electrochem. Soc. 147 (2000) 1080.

[12] G.I. Lacconi, G. Sandmann, W. Plieth, in: M. Paunovic, et al. (Eds.), Electrochemical Society Proceedings, vol. 97-27, Electrochemical Society, Pennington, New Jersey, 1997.

[13] R.N. Bhattacharya, A.M. Fernandez, Sol. Energy Mater. Sol. Cells 76 (2003) 331-337.

[14] S. Jost, F. Hergert, R. Hock, J. Schulze, A. Kirbs, T. Voß, M. Purwins, M. Schmid, Sol. Energy Mater. Sol. Cells 91 (2007) 636. 